\title{
Systematic Review \\ In Vivo Antibacterial Efficacy of Nanopatterns on Titanium Implant Surface: A Systematic Review of the Literature
}

\author{
Yang Sun ${ }^{1} \mathbb{D}$, Yang Yang ${ }^{1,2}$, Weibo Jiang ${ }^{1}$, Haotian Bai ${ }^{1} \mathbb{D}$, He Liu $^{1}\left(\mathbb{D}\right.$ and Jincheng Wang ${ }^{1, *(\mathbb{D})}$ \\ 1 Orthopaedic Medical Center, The Second Hospital of Jilin University, Changchun 130041, China; \\ sunyang@jlu.edu.cn (Y.S.); yangyang7019@mails.jlu.edu.cn (Y.Y.); weibo0515@163.com (W.J.); \\ baihaotian@jlu.edu.cn (H.B.); heliu@jlu.edu.cn (H.L.) \\ 2 Engineering Research Centre of Molecular Diagnosis and Cell Treatment for Metabolic Bone Disease, \\ The Second Hospital of Jilin University, Changchun 130041, China \\ * Correspondence: jinchengwang@hotmail.com
}

\section{check for} updates

Citation: Sun, Y.; Yang, Y.; Jiang, W.; Bai, H.; Liu, H.; Wang, J. In Vivo Antibacterial Efficacy of Nanopatterns on Titanium Implant Surface: A Systematic Review of the Literature. Antibiotics 2021, 10, 1524. https://doi.org/10.3390/ antibiotics10121524

Academic Editors: Catherine Mullié, Nicholas Dixon and Elena

Maria Varoni

Received: 31 October 2021

Accepted: 10 December 2021

Published: 14 December 2021

Publisher's Note: MDPI stays neutral with regard to jurisdictional claims in published maps and institutional affiliations.

Copyright: (C) 2021 by the authors. Licensee MDPI, Basel, Switzerland. This article is an open access article distributed under the terms and conditions of the Creative Commons Attribution (CC BY) license (https:/ / creativecommons.org/licenses/by/ $4.0 /)$.

\begin{abstract}
Background: Bionic surface nanopatterns of titanium (Ti) materials have excellent antibacterial effects in vitro for infection prevention. To date, there is a lack of knowledge about the in vivo bactericidal outcomes of the nanostructures on the Ti implant surfaces. Methods: A systematic review was performed using the PubMed, Embase, and Cochrane databases to better understand surface nanoscale patterns' in vivo antibacterial efficacy. The inclusion criteria were preclinical studies (in vivo) reporting the antibacterial activity of nanopatterns on Ti implant surface. Ex vivo studies, studies not evaluating the antibacterial activity of nanopatterns or surfaces not modified with nanopatterns were excluded. Results: A total of five peer-reviewed articles met the inclusion criteria. The included studies suggest that the in vivo antibacterial efficacy of the nanopatterns on Ti implants surfaces seems poor. Conclusions: Given the small number of literature results, the variability in experimental designs, and the lack of reporting across studies, concluding the in vivo antibacterial effectiveness of nanopatterns on Ti substrates' surfaces remains a big challenge. Surface coatings using metallic or antibiotic elements are still practical approaches for this purpose. High-quality preclinical data are still needed to investigate the in vivo antibacterial effects of the nanopatterns on the implant surface.
\end{abstract}

Keywords: titanium implant; nanopattern; surface morphology; antibacterial; biofilm formation

\section{Introduction}

In the past few decades, with the rapid development of material science and biomedical technology, biomedical metal materials have been widely used in the manufacture of artificial joints, bone trauma fixation, and other osseous tissue replacement or repair medical devices, where titanium (Ti) has become the preferred material due to its similarity with the biomechanical characteristics of human bones and the excellent biocompatibility [1,2]. While many researchers focus on improving the osseointegration ability of Ti implants, the occurrence of postoperative infection, as one of the most severe complications after implantation, cannot be overlooked [3,4]. The infection not only leads to the failure of the implant and the surgery but also increases the patients' recovery period and makes an economic burden on both patients and the medical system [5]. Although surgical techniques and concepts of sterility have improved in recent years, the average postoperative infection rate is still as high as $2-5 \%[3,6,7]$.

The use of antibiotics is a common and effective way to control this issue, but the reason why implant-related infections are challenging to treat lies in the formation of bacterial biofilm on the implant surface. This structure is mainly composed of polysaccharide polymers secreted by bacteria, which can protect the bacteria and resist various antibiotics from outside the biofilm [8]. In addition, the system-administered anti-infection method can also result in a low concentration of drugs in the surgical area due to scars or fibrosis of 
the surrounding tissues, and thus affects the antibacterial efficiency $[5,9,10]$. Meanwhile, the extensive use of antibiotics brings the problem of microbial resistance. Surface modifications such as the antibiotic or metallic coating on the implant surface provides more peri-implant antibacterial activity than traditional methods, thus showing an excellent antibacterial effect [11]. However, the antibacterial ability of coating will gradually weaken with the release of antibacterial substances. Moreover, the antibacterial metal ions released from coatings have intrinsic cytotoxicity and may affect the osseointegration performance of Ti implants [12,13].

It has been shown that modifying the surface morphology of Ti materials without adding other chemical reagents can achieve long-term antibacterial effects and inhibit biofilm formation in vitro [14-16]. The presence of nano-protrusions on the bionic nanopatterns leads to the destruction and death of the microbes through direct contact and stress concentration [5,17]. The development of surface nanopatterns with efficient antibacterial properties may enable the better clinical application of Ti-related medical materials and address the bacterial resistance problem caused by antibiotic abuse [5]. However, the interactions between nanopatterns and bacteria can be multifaceted, and the antibacterial efficiency in vivo and the role of various factors in regulating bactericidal behavior of the nanopatterns on the Ti implant surface remain unclear $[18,19]$.

This article summarizes and analyzes the preclinical studies of the nanoscale patterns' antibacterial behaviors on the Ti implant surface to draw a clearer view of the in vivo antibacterial efficacy of bionic nanoscale patterns for the future Ti implant surface bactericidal modification research and applications.

\section{Results}

\subsection{Identification and Selection of Studies}

Electronic database searches identified 145 articles (Figure 1). After titles and abstracts were screened for relevance, 78 articles were deemed irrelevant per the inclusion and exclusion criteria. Of the 59 full texts of the in vivo animal studies assessed for eligibility, 5 were selected and reviewed after applying the inclusion and exclusion criteria. The 54 excluded articles did not evaluate the antibacterial activity of nanopatterns or did not modify Ti surfaces with nanopatterns. Meta-analysis was not conducted due to the scarcity and heterogeneity of the studies.

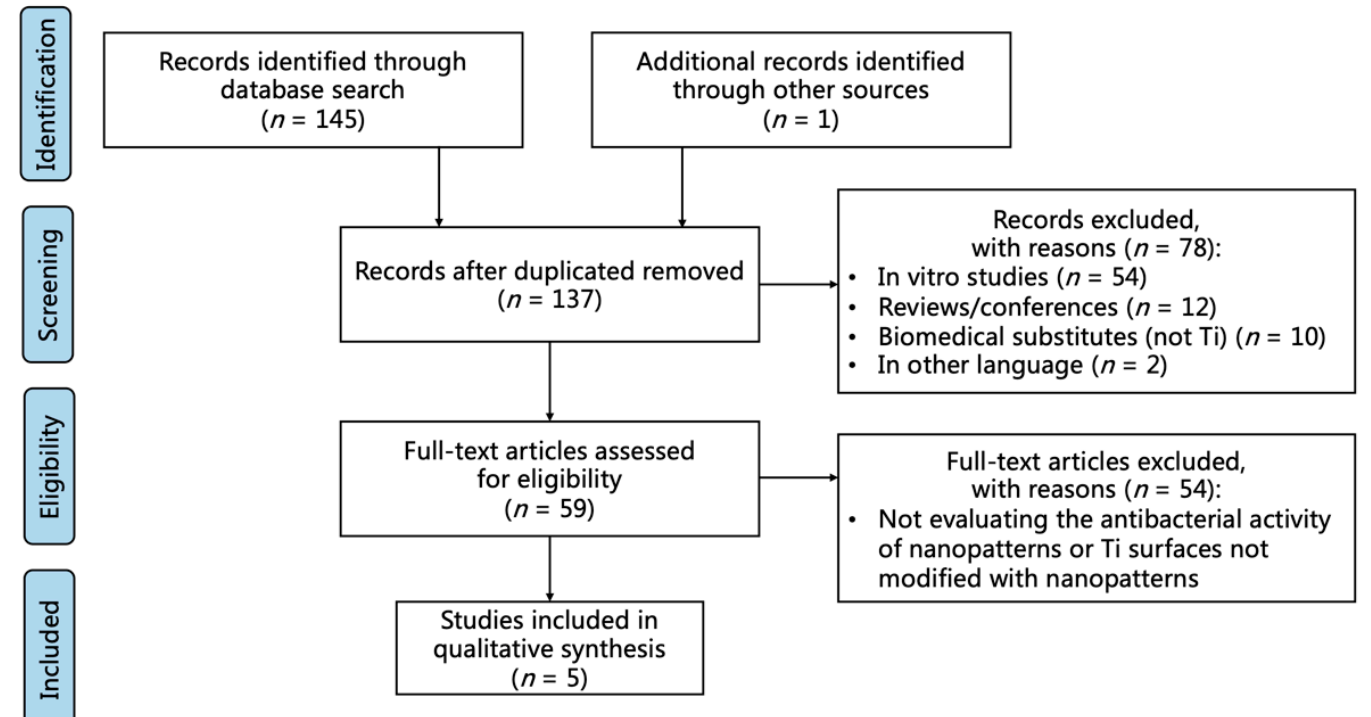

Figure 1. PRISMA (Preferred Reporting Items for Systematic Reviews and Meta-Analyses) diagram including study algorithm. 


\subsection{Study Characteristics}

Tables 1 and 2 provide a general description of the characteristics of the included studies. The five studies used three experimental models (rabbit [20], rat [21-23], and mice [24]). Sample sizes varied between 20 [22] and 45 animals [23]. All the studies performed the evaluation of the in vivo antibacterial activity of nanopatterns themselves on the surfaces of the Ti implants. Among these, one study focused on evaluating the antibacterial efficacy of nanopatterns alone on the implant surface [24]. Another evaluated the antibacterial effect of $\mathrm{Ag}$ and polydopamine as additional agents to the nanorods (NRDs) on the implant surface [22]. Two studies evaluated the antibacterial effect of metallic agents ( $\mathrm{Ag}$ and $\mathrm{Mg}$, respectively) as additional modifications on the NTs and NRDs, respectively, on the implant surface [22,23]. One study evaluated the antibacterial effect of fluorine (F)-incorporated NRDs on the implant surface [20]. The monitoring period ranged from 2 days [24] to 8 weeks [20]. All the studies assessed the antibacterial activity of nanopatterns alone on the surfaces. Only one study reported excellent antibacterial efficacy of nanopatterns alone on the implant surface [24]. The most frequently used shape of the implant was a cylinder, and the most used measurement method for in vivo antibacterial efficiency evaluation was bacterial culture and histopathological analysis.

Table 1. Study characteristics.

\begin{tabular}{|c|c|c|c|c|c|c|}
\hline Studies & $\begin{array}{c}\text { Animal Model } \\
(n)\end{array}$ & $\begin{array}{l}\text { Location of } \\
\text { Implant } \\
\text { Placement }\end{array}$ & $\begin{array}{c}\text { Bacteria and } \\
\text { Infection Set-Up }\end{array}$ & Follow-Up & $\begin{array}{c}\text { In Vivo } \\
\text { Antibacterial } \\
\text { Efficacy Measures }\end{array}$ & $\begin{array}{l}\text { In Vivo Antibacterial } \\
\text { Efficacy Conclusions } \\
\text { (nanopatterns) }\end{array}$ \\
\hline $\begin{array}{c}\text { Zhang } \\
\text { et al., } 2013 \\
{[21]}\end{array}$ & $\begin{array}{l}\text { Sprague Dawley } \\
\text { rat (36) }\end{array}$ & $\begin{array}{l}\text { Femoral } \\
\text { intercondylar } \\
\text { fossa }\end{array}$ & $\begin{array}{c}\text { S. aureus. bacterial } \\
\text { suspension }\left(10^{7}\right. \\
\text { CFU } / 100 \mu \mathrm{L}, 100 \mu \mathrm{L}) \\
\text { was introduced into } \\
\text { the femoral canal } \\
\text { through the hole in } \\
\text { the femoral } \\
\text { intercondylar fossa. }\end{array}$ & 30 days & $\begin{array}{c}\text { Clinical assessment } \\
\text { Bacterial Culture }\end{array}$ & $\begin{array}{l}\text { Although better than } \\
\text { the pure } \mathrm{Ti}^{\mathrm{T}} \mathrm{TiO}_{2} \mathrm{NTs} \\
\text { showed a poor } \\
\text { antibacterial effect } \\
\text { in vivo. }\end{array}$ \\
\hline $\begin{array}{l}\text { Zhou et al., } \\
2017 \text { [20] }\end{array}$ & $\begin{array}{l}\text { New Zealand } \\
\text { rabbit (24) }\end{array}$ & Left femur & $\begin{array}{c}\text { PBS-diluted } \\
\text { suspension of } \\
\text { S. aureus }\left(10^{5}\right. \\
\text { CFU / mL, } 20 \mu \mathrm{L}) \text { was } \\
\text { injected into the } \\
\text { medullary cavity of } \\
\text { the femur. }\end{array}$ & 8 weeks & $\begin{array}{l}\text { Bacterial Culture } \\
\text { CFU Counting }\end{array}$ & $\begin{array}{l}{\mathrm{The} \mathrm{Sr}_{1} \text {-HA NRDs on }} \text { microporous } \mathrm{TiO}_{2} \\
\text { showed no } \\
\text { antibacterial activity } \\
\text { in vivo. }\end{array}$ \\
\hline $\begin{array}{l}\text { Guan et al., } \\
2019 \text { [22] }\end{array}$ & $\begin{array}{l}\text { Sprague Dawley } \\
\text { rat (20) }\end{array}$ & $\begin{array}{l}\text { Tibia plateau of } \\
\text { the right knee }\end{array}$ & $\begin{array}{c}30 \mu \mathrm{L} \text { bacteria } \\
\text { suspension }(\mathrm{MRSA} \text {, } \\
\left.1.5 \times 10^{6} \mathrm{CFU} / \mathrm{mL}\right) \\
\text { was injected into the } \\
\text { exposed tibia hole. }\end{array}$ & 4 weeks & $\begin{array}{c}\text { X-ray } \\
\text { Micro-CT } \\
\text { Histopathological } \\
\text { analysis }\end{array}$ & $\begin{array}{l}\text { Same as the pure } \mathrm{Ti} \\
\text { group, } \mathrm{TiO}_{2} \text { NRDs } \\
\text { did not show } \\
\text { antibacterial activity } \\
\text { in vivo. }\end{array}$ \\
\hline $\begin{array}{l}\text { Yang et al., } \\
2019 \text { [23] }\end{array}$ & $\begin{array}{l}\text { Sprague Dawley } \\
\text { rat }(45)\end{array}$ & $\begin{array}{c}\text { Femoral } \\
\text { medullary cavity } \\
\text { at the middle of } \\
\text { intercondylar } \\
\text { fossa }\end{array}$ & $\begin{array}{c}50 \mu \mathrm{L} \text { of PBS } \\
\text { containing MRSA at a } \\
1 \times 10^{6} \mathrm{CFU} / \mathrm{mL} \\
\text { concentration was } \\
\text { injected into the } \\
\text { medullary cavity. }\end{array}$ & 5 weeks & $\begin{array}{c}\text { X-ray } \\
\text { Micro-CT } \\
\text { Histopathological } \\
\text { analysis }\end{array}$ & $\begin{array}{l}\text { The NT structure } \\
\text { itself demonstrated } \\
\text { limited antimicrobial } \\
\text { activities in vivo. }\end{array}$ \\
\hline $\begin{array}{c}\text { Zhang } \\
\text { et al., } 2021 \\
{[24]}\end{array}$ & $\begin{array}{l}\text { Kunming mice } \\
(24)\end{array}$ & $\begin{array}{l}\text { Subcutaneous } \\
\text { tissue on the back } \\
\text { and tibia }\end{array}$ & $\begin{array}{l}\text { Antibacterial assay: } \\
\text { samples were soaked } \\
\text { in } 50 \mu \mathrm{L} \text { of } S \text {. aureus } \\
\left(1 \times 10^{7} \mathrm{CFU} / \mathrm{mL}\right) \\
\text { for } 1 \mathrm{~h} \text { and then } \\
\text { implanted. } \\
\text { Antibiofilm assay: } \\
\text { samples were } \\
\text { cultivated in } 2 \mathrm{~mL} \text { of } \\
\text { the } S . \text { aureus solution } \\
\left(10^{7} \mathrm{CFU} / \mathrm{mL}\right) \text { to } \\
\text { form biofilms. }\end{array}$ & 2-14 days & $\begin{array}{c}\text { Bacterial Culture } \\
\text { Histopathological } \\
\text { analysis }\end{array}$ & $\begin{array}{c}\mathrm{TiO}_{2} \text { nanostructures } \\
\text { under the irradiation } \\
\text { of } 808 \mathrm{~nm} \text { NIR light } \\
\text { had an excellent } \\
\text { anti-biofilm effect } \\
\text { in vivo. }\end{array}$ \\
\hline
\end{tabular}

CFU: Colony-Forming Unit; HA: hydroxyapatite; S. aureus: Staphylococcus aureus; MRSA: methicillin-resistant Staphylococcus aureus; NRDs: nanorods; NTs: nanotubes; NIR: near-infrared; Sr: strontium; Ti: titanium. 
Table 2. Implant characteristics and in vivo antibacterial activities (Outcomes).

\begin{tabular}{|c|c|c|c|c|c|c|}
\hline Studies & $\begin{array}{c}\text { Implants } \\
\text { Number (n) }\end{array}$ & $\begin{array}{l}\text { Implant Dimensions } \\
\mathrm{D}(\varnothing) \times \mathrm{L}(\mathrm{mm})\end{array}$ & $\begin{array}{l}\text { Ti Implant } \\
\text { Shape }\end{array}$ & $\begin{array}{c}\text { Surface } \\
\text { Nanopatterns }\end{array}$ & $\begin{array}{l}\text { Nanopattern } \\
\text { Dimensions D } \\
(\varnothing) \times \text { L }(\mathrm{nm})\end{array}$ & $\begin{array}{c}\text { In Vivo } \\
\text { Antibacterial } \\
\text { Activities } \\
\text { (Nanopatterns) }\end{array}$ \\
\hline $\begin{array}{c}\text { Zhang } \\
\text { et al., 2013 } \\
\text { [21] }\end{array}$ & 36 & $1(\varnothing) \times \mathrm{L} 20$ & Cylinder & $\mathrm{TiO}_{2} \mathrm{NTs}$ & $80(\varnothing) \times$ L 800 & $\begin{array}{l}\text { The infection rate } \\
\text { was lower in the NT } \\
\text { group compared to } \\
\text { the Cp-Ti group ( } 92 \% \\
\text { vs. } 100 \%) \text {. }\end{array}$ \\
\hline $\begin{array}{c}\text { Zhou } \\
\text { et al., 2017 } \\
\text { [20] }\end{array}$ & 120 & $2(\varnothing) \times \mathrm{L} 10$ & Cylinder & $\begin{array}{c}\mathrm{Sr}_{1} \text {-HA NRDs } \\
\text { on microporous } \\
\mathrm{TiO}_{2}\end{array}$ & $\begin{array}{c}\text { NRDs } \varnothing \text { and } \\
\text { interrod } \\
\text { spacing: } 70 \pm 6 \\
\text { Pore } \varnothing: \\
\text { 1000-3000 }\end{array}$ & $\begin{array}{c}\text { The average CFU } \\
\text { counting results } \\
\text { exhibited the } \mathrm{Sr}_{1}-\mathrm{HA} \\
\text { NRDs on } \\
\text { microporous } \mathrm{TiO}_{2} \\
\text { did not possess } \\
\text { antibacterial activity } \\
\text { against } S \text {. aureus } \\
\text { in vivo. }\end{array}$ \\
\hline $\begin{array}{c}\text { Guan } \\
\text { et al., 2019 } \\
\text { [22] }\end{array}$ & 20 & $1(\varnothing) \times \mathrm{L} 10$ & Cylinder & $\mathrm{TiO}_{2}$ NRDs & $\begin{array}{c}50-100(\varnothing) \times L \\
1000-2000\end{array}$ & $\begin{array}{l}\mathrm{TiO}_{2} \text { NRDs showed } \\
\text { no difference in the } \\
\text { infection rate } \\
\text { compared to the pure } \\
\text { Ti group. }\end{array}$ \\
\hline $\begin{array}{l}\text { Yang et al., } \\
2019 \text { [23] }\end{array}$ & 45 & $2(\varnothing) \times \mathrm{L} 15$ & Cylinder & $\mathrm{TiO}_{2} \mathrm{NTs}$ & $80(\varnothing)$ & $\begin{array}{l}\text { The NT structure } \\
\text { itself exhibited slight } \\
\text { anti-infection } \\
\text { potential in vivo, but } \\
\text { the NTs structure } \\
\text { alone could not } \\
\text { combat such a severe } \\
\text { implant-related bone } \\
\text { infection. }\end{array}$ \\
\hline $\begin{array}{c}\text { Zhang } \\
\text { et al., 2021 } \\
\text { [24] }\end{array}$ & + & 10 (length) $\times($ wide $) 5$ & Foil & $\mathrm{TiO}_{2}$ NRDs & $\begin{array}{l}\text { Nanoleaf; } \\
\text { NRDs: 40-50 } \\
(\varnothing) \times \text { L } 1000\end{array}$ & $\begin{array}{l}\text { The } \mathrm{TiO}_{2} \text { NRDs } \\
\text { arrays under } \\
\text { irradiation with } \\
808 \text { NIR light } \\
\text { produced excellent } \\
\text { antibacterial activity } \\
\text { in vivo and could } \\
\text { eradicate the } \\
\text { attached biofilms on } \\
\text { the implant surface. }\end{array}$ \\
\hline
\end{tabular}

CFU: Colony-Forming Unit; Cp-Ti: commercially pure titanium; HA: hydroxyapatite; NIR: near-infrared; PBS: phosphate buffered saline; Sr: strontium; S. aureus: Staphylococcus aureus; NRDs: nanorods; NTs: nanotubes; Ti: titanium.

\subsection{Risk of Bias and Quality Assessment of the Studies}

Assessment of the risk of bias according to SYRCLE (Systematic Review Center for Laboratory Animal Experimentation) guidelines was performed [25]. The included studies presented heterogeneous levels of risk of bias (Figure 2). The evaluation and scoring of the quality of the studies according to ARRIVE (Animal Research: Reporting of In Vivo Experiments) criteria [26,27] (Table S1) yielded an average score of 17.3. None of the studies reported item 19 (Replace, Reduce and Refine) or item 20 (Adverse events) in the abstract. Only one of the studies reported item 22 (Generalization/Applicability) [22] and item 5 
(Reasons for animal models) [20]. One of the studies failed to report item 13 (Assignment of animals to experimental groups) [20].

\begin{tabular}{|c|c|c|c|c|c|}
\hline & $\begin{array}{l}\text { Zhang et al. } \\
\quad 2013\end{array}$ & $\begin{array}{l}\text { Zhou et al. } \\
\quad 2017\end{array}$ & $\begin{array}{l}\text { Guan et al. } \\
\quad 2019\end{array}$ & $\begin{array}{l}\text { Yang et al. } \\
2019\end{array}$ & $\begin{array}{l}\text { Zhang et al. } \\
\quad 2021\end{array}$ \\
\hline \multicolumn{6}{|l|}{$\begin{array}{l}\text { Q10: Was the study apparently free of other problems that could result in high } \\
\text { risk of bias? (Other) }\end{array}$} \\
\hline \multicolumn{6}{|l|}{$\begin{array}{l}\text { Q9: Are reports of the study free of selective outcome reporting? } \\
\text { (Reporting) }\end{array}$} \\
\hline \multicolumn{6}{|l|}{$\begin{array}{l}\text { Q8: Were incomplete outcome data adequately addressed? } \\
\text { (Attrition) }\end{array}$} \\
\hline \multicolumn{6}{|l|}{$\begin{array}{l}\text { Q7: Was the outcome assessed or blinded? } \\
\text { (Detection) }\end{array}$} \\
\hline \multicolumn{6}{|l|}{$\begin{array}{l}\text { Q6: Were animals selected at random for outcome assessment? } \\
\text { (Detection) }\end{array}$} \\
\hline \multicolumn{6}{|l|}{$\begin{array}{l}\text { Q5: Were the caregivers and/or investigators blinded from knowledge of which } \\
\text { intervention each animals received during the experiment? (Performance) }\end{array}$} \\
\hline \multicolumn{6}{|l|}{$\begin{array}{l}\text { Q4: Were the animals randomly housed during the experiment? } \\
\text { (Performance) }\end{array}$} \\
\hline \multicolumn{6}{|l|}{$\begin{array}{l}\text { Q3: Was the allocation adequately concealed? } \\
\text { (Selection) }\end{array}$} \\
\hline $\begin{array}{l}\text { Q2: Were the groups similar at baseline or were they adjusted for confounders } \\
\text { in the analysis? (Selection) }\end{array}$ & & & & & \\
\hline $\begin{array}{l}\text { Q1: Was the allocation sequence adequately generated and applied? } \\
\text { (Selection) }\end{array}$ & & & & & \\
\hline
\end{tabular}

Figure 2. Risk of bias assessment results based on SYRCLE's (Systematic Review Centre for Laboratory Animal Experimentation) risk of bias tool. White indicates low risk; black high risk; and gray unclear risk [20-24].

\section{Discussion}

Modifying the surface nanopattern of materials to achieve antibacterial properties has attracted much attention in the past decade [14-16]. It has been shown that the surface morphology of insect wings such as dragonflies and cicadas has excellent antibacterial and antifungal properties $[17,28,29]$. With the presence of physical nano-protrusions on the surface of insect wings, the antibacterial properties may be attributable to the fact that when microbial cells encounter the surface protrusions, they increase the stress and deformation of the microbial cell membrane structure, leading to their destruction and ultimately leading to cell dissolution and deaths $[5,17]$. Investigating the surface nanostructure of insect wings and preparing bionic nanopatterns on Ti-based materials according to it has emerged as new ideas for preparing modern antibacterial implants. The modification of the surface morphology of $\mathrm{Ti}$ implant to obtain or improve antibacterial ability without adding other chemical reagents, such as silver $(\mathrm{Ag})$ or antibiotics, has been widely reported in ex vivo studies $[5,15]$.

However, the in vivo experimental studies that we retrieved and reviewed did not provide factual data to support this view. Only one study provided evidence that the surface nanostructure on Ti implant has anti-infective effects in vivo [24]. The remaining four articles either indicated that the nanopatterns did not exhibit antibacterial activity in vivo at all [20,22] or only showed limited antibacterial efficacy [21,23]. Moreover, the in vivo antibacterial activity mechanisms of the Ti implant surface morphology seem more complex than just physical puncturing. By modification of the surface morphology on $\mathrm{Ti}$ foil using $\mathrm{TiO}_{2}$ NRDs, Zhang et al. reported that the NRD arrays under irradiation with 808 near-infrared (NIR) light produced excellent antibacterial activity against Staphylococcus aureus in vivo through the combined actions of hyperthermia, reactive oxygen species (ROS), and puncturing effects, and could eradicate the attached biofilms on the implant surface in a Kumming mice model [24].

The effect of inhibiting the formation of biofilms is generally considered relevant to the anti-adhesion properties of the surface morphology [30-32]. Compared with the patterned surfaces, bacteria were reported more likely to adhere to smoother surfaces [32-35]. In the study reported by Guan et al., the bacterial coverage on the $\mathrm{TiO}_{2} \mathrm{NRDs}$ samples was 
significantly lower than the bacterial coverage on the pure Ti group that formed a typical biofilm after $48 \mathrm{~h}$ ex vivo. The authors attributed this to the anti-adhesion effect of the topography on the implant. However, their in vivo experiment results using a Sprague Dawley rat model did not show the antibacterial activity of the $\mathrm{TiO}_{2} \mathrm{NRDs}$, and there was no difference in the infection rate between the $\mathrm{TiO}_{2} \mathrm{NRDs}$ and pure Ti groups [22].

Antibacterial agents can be added to the surface of Ti materials to obtain/improve bactericidal properties [36-38]. Most of the studies in this regard were focused on the preparation of antibacterial metal nanoparticles (NPs) fixed on the surface of the Ti substrate by using a carrier or coated on the surface to achieve strong antibacterial ability, good biocompatibility, and stability $[36,39,40]$. The common metal particles selected for this purpose are $\mathrm{Ag}, \mathrm{Cu}$, zinc $(\mathrm{Zn})$, magnesium $(\mathrm{Mg})$, etc., which present antibacterial activities by generating ROS, destroying the structure of bacterial membranes, or regulating the signal transduction pathway of bacteria [41-44]. Among these, the advantages of a broad spectrum of antibacterial activity make Ag the most studied and widely used metalbased antibacterial agent on Ti substrates [45-47]. Ag NPs have been proven to have a good killing effect on both Gram-positive cocci (e.g., S. aureus) and Gram-negative bacilli (e.g., Escherichia coli) [48-50]. In the study reported by Guan et al., a novel surface strategy involving the formation of polydopamine (PDA) and Ag nanoparticle-loaded $\mathrm{TiO}_{2}$ NRDs coatings on Ti alloy was developed. In vitro antibacterial experiments showed that, compared to the pure Ti group, the Ag- $\mathrm{TiO}_{2} @ \mathrm{PDA}$ NRDs coating group had adequate antibacterial effects at 7 and 14 days, according to the bacterial counting results. The efficacies were $88.6 \pm 1.5 \%$ and $80.1 \pm 1.1 \%$, respectively, against methicillin-resistant S. aureus, and $91.3 \pm 0.5 \%$ and $86.2 \pm 2.6 \%$ against $E$. coli. Nevertheless, their $\mathrm{TiO}_{2} \mathrm{NRDs}$ group also showed a $22.3 \pm 3.9 \%$ antibacterial efficacy for methicillin-resistant $S$. aureus (MRSA) and $25.4 \pm 12.3 \%$ for $E$. coli. During the in vivo experiments, the materials were implanted into the tibia of a MRSA infected Sprague Dawley rat model. After four weeks, the results of X-ray, micro-CT, and histopathological analysis showed that MRSA could be killed by Ag+, confirming that the $\mathrm{Ag}-\mathrm{TiO}_{2} @ \mathrm{PDA}$ NRDs coating also had good antibacterial activity in vivo. However, same as the pure Ti group, $\mathrm{TiO}_{2} \mathrm{NRDs}$ on the surface did not show antibacterial activity in vivo [22].

Although the metallic agents can serve as excellent antibacterial elements on the $\mathrm{Ti}$ implant surface, the biggest challenge lies in enabling the stable release of such agents at a suitable concentration on the surface of the implants [51,52]. Metal ions released by the coatings are highly mobile and cytotoxic, and their entrance into living cells with high concentrations can kill healthy cells [53]. One solution to this problem is to create nanotube (NT) patterns on the surface of the substrate and load them into the structures for a controlled releasing and long-term antibacterial effect [47,54]. In the study performed by Yang et al., Mg-incorporated NT-modified Ti implants (NT-Mg) were designed and tested to measure the antimicrobial properties. The results demonstrated that NT-Mg implants maintained continuous and reliable release of $\mathrm{Mg}$ ion from the NTs, producing long-lasting antimicrobial activity both in vitro and in vivo. The nanotubular structure and alkaline microenvironment during degradation were the two main reasons responsible for the antimicrobial properties of NT-Mg. However, although the nanotubular structure itself exhibited slight anti-infection potential in vivo, the nanotubular structure alone could not combat such a severe implant-related bone infection [23].

In recent years, to avoid the cytotoxicity of the metal ion as the antibacterial agent, studies of non-metallic elements serving as the bactericidal agent of the surface of Ti implants have emerged [20,55-57]. It has been reported that fluorine (F)-doped nanopatterns on Ti material surfaces have excellent antibacterial ability against numerous bacteria in vitro and good cytocompatibility and osteoblastic activity $[20,55,58,59]$. In the study reported by Zhou et al., F-doped $\mathrm{Sr}_{1}$-HA (strontium containing hydroxyapatite) NRDs on microporous $\mathrm{TiO}_{2}$ implant led to the significantly improved antibacterial activities in a S. aureus infected New Zealand rabbit model at 8 weeks according to the bacteria counting results, and the effect was related to the incorporated F dose. However, the average CFU counting results 
exhibited the $\mathrm{Sr}_{1}$-HA NRDs on microporous $\mathrm{TiO}_{2}$ did not possess antibacterial activity against $S$. aureus in vivo at 8 weeks [20].

In addition to the inorganic antibacterial agents coating strategies, the antibiotic coating can also be added to the Ti implant surface to achieve antibacterial effects [60-63]. Under ideal conditions, the antibiotics loaded on the surface should release in a controlled path and speed, reach the effective drug concentration, and maintain a long sufficient sterilization time, reducing the risk of bacterial resistance problems caused by antibiotic abuse [64-66]. Considering that both aerobic and anaerobic organisms can cause bone infections and the high frequency of polymicrobial infections [67-69], broad-spectrum antibiotics such as rifampicin, gentamicin, vancomycin, etc., are recommended as the loaded agents $[70,71]$. Under ideal conditions, the antibiotics released by the prepared nanomaterials should reach the effective drug concentration and maintain a long sufficient sterilization time [64,72]. Zhang et al. compared the antibacterial efficacy of $\mathrm{TiO}_{2} \mathrm{NTs}$ loaded with vancomycin (NT-V) with those of the NTs and commercially pure (Cp-Ti) groups in an S. aureus infected Sprague Dawley rat model. Compared with the other groups, NT-V showed an excellent antibacterial effect both in vitro and in vivo. Although the NTs reduced the surface bacterial adhesion in vitro, implant infection still developed in the in vivo experiments. The infection rate in the NT-V group was $0 \%$ at 30 days, while that of the NT and Cp-Ti groups reached $92 \%$ and $100 \%$, respectively [21]. Although S. aureus is the primary pathogen responsible for bone infections [73-75], the evaluation of the in vivo anti-Staphylococcus activity alone further undermined the clinical translation value of the studies retrieved.

This systematic review has several limitations. Although a systematic literature search was performed and no similar reviews were identified, the registration of this systematic review was not completed before the data extraction was finished, and the limited number of studies and heterogeneity in reporting and experimental designs may influence outcomes, hinder result comparison, and preclude meta-analysis. Additionally, the findings of this review are supported by basic science studies (level 3). No studies of level 2 evidence or higher were identified. Finally, it is possible all relevant articles were not identified with our search criteria.

\section{Materials and Methods}

\subsection{Systematic Literature Search}

A comprehensive systematic literature search was conducted to answer the question, "Is the in vivo antibacterial efficacy of Ti implant enhanced by surface nanomorphology modification alone?" following the PRISMA (Preferred Reporting Items for Systematic Reviews and Meta-Analyses) guidelines [76]. The systematic search was conducted in August 2021 using three electronic databases: PubMed, Embase, and Cochrane. A general search was conducted using the following terms: ("nano"(All Fields) OR "nano-scale"(All Fields) OR "nanopattern"(All Fields) OR "nanomorphology"(All Fields) OR "nanostructure"(All Fields)) AND ("surface"(All Fields) OR "surfaces"(All Fields) OR "surfacing"(All Fields)) AND ("antimicrobial"(All Fields) OR "antibacterial"(All Fields)) AND ("titanium"(MeSH Terms) OR “titanium"(All Fields)) AND ("implantation"(All Fields) OR “implant"(All Fields) OR “implants"(All Fields)) AND “animals"(MeSH Terms).

The results were filtered to English and full-text articles. References from the articles were reviewed to confirm the completeness of the identified literature.

\subsection{Exclusion and Inclusion Criteria}

In vivo peer-reviewed studies evaluating the antibacterial efficacy of nanopatterns on Ti implant surfaces were included in this systematic review. Exclusion criteria for all studies were as follows: articles not written in English; review and expert opinion articles, conference proceedings, and presentations; ex vivo studies; studies that did not evaluate the antibacterial activity of nanopatterns or did not modify Ti surfaces with nanopatterns (Table S2). One author (Y.S.) performed the literature search, and two authors (Y.S., Y.Y.) 
independently reviewed the search results. Titles and abstracts were reviewed for all search results. Full-text articles were obtained to determine studies that met inclusion and exclusion criteria. If disagreement occurred, the senior author (J.W.) was consulted.

\section{Conclusions}

In contrast with the widely reported excellent in vitro antibacterial effectiveness, the in vivo antibacterial efficacy of the nanopatterns on Ti implants' surfaces seems poor according to the preclinical studies we assessed. Moreover, given the small number of literature results, the variability in experimental designs, and the lack of reporting across studies, concluding the in vivo antibacterial effectiveness of the nanostructures on $\mathrm{Ti}$ substrates' surfaces remains a big challenge. Surface modifications using metallic NPs or antibiotics coating are still practical approaches for achieving or improving the in vivo bactericidal activities. Despite our inability to ascertain the in vivo antibacterial efficacy of the surface nanopatterns, high-quality preclinical data are still needed to investigate the antibacterial effects of the nanopatterns on the implant surface and the mechanisms.

Supplementary Materials: The following are available online at https: / www.mdpi.com/article/ 10.3390/antibiotics10121524/s1, Table S1: Checklist of ARRIVE criteria reported by the included studies, Table S2: Study inclusion and exclusion criteria.

Author Contributions: All the authors contributed to the conceptualization and design of this review. Data collection (literature search and study selection): Y.S. and Y.Y.; data analysis and interpretation: Y.S., Y.Y. and J.W.; writing—original draft preparation, Y.S., Y.Y., W.J., H.B., H.L. and J.W.; writingreview and editing, W.J. and J.W.; funding acquisition, Y.S. and J.W. All authors have read and agreed to the published version of the manuscript.

Funding: This study was funded by the Finance Department of Jilin Province, P.R. China (Grant Number 3D5197435429 and 3D5204944429), and the Science and Technology Department of Jilin Province, P.R. China (Grant Number 3D5203928429 and 3D5204471429).

Data Availability Statement: Not applicable.

Acknowledgments: The authors appreciate Jichao Liu and Shiyan Yang (Division of Orthopedics, Second Hospital of Jilin University, Jilin, China) for giving suggestions on the method design and data collection in this study.

Conflicts of Interest: The authors declare no conflict of interest.




SYRCLE Systematic Review Center for Laboratory Animal Experimentation

Ti titanium

Zn zinc

\section{References}

1. Gittens, R.A.; Olivares-Navarrete, R.; Schwartz, Z.; Boyan, B.D. Implant osseointegration and the role of microroughness and nanostructures: Lessons for spine implants. Acta Biomater. 2014, 10, 3363-3371. [CrossRef]

2. Souza, J.C.M.; Sordi, M.B.; Kanazawa, M.; Ravindran, S.; Henriques, B.; Silva, F.S.; Aparicio, C.; Cooper, L.F. Nano-scale modification of titanium implant surfaces to enhance osseointegration. Acta Biomater. 2019, 94, 112-131. [CrossRef] [PubMed]

3. Roy-Chaudhury, P.; Munda, R. Infections associated with surgical implants. N. Engl. J. Med. 2004, 351, $193-195$.

4. Pfang, B.G.; García-Cañete, J.; García-Lasheras, J.; Blanco, A.; Auñón, Á.; Parron-Cambero, R.; Macías-Valcayo, A.; Esteban, J. Orthopedic Implant-Associated Infection by Multidrug Resistant Enterobacteriaceae. J. Clin. Med. 2019, 8, 220. [CrossRef] [PubMed]

5. Liu, J.; Liu, J.; Attarilar, S.; Wang, C.; Tamaddon, M.; Yang, C.; Xie, K.; Yao, J.; Wang, L.; Liu, C.; et al. Nano-modified titanium implant materials: A way toward improved antibacterial properties. Front Bioeng. Biotechnol. 2020, 8, 576969. [CrossRef]

6. Darouiche, R.O. Treatment of infections associated with surgical implants. N. Engl. J. Med. 2004, 350, 1422-1429. [CrossRef]

7. Tanner, M.C.; Fischer, C.; Schmidmaier, G.; Haubruck, P. Evidence-based uncertainty: Do implant-related properties of titanium reduce the susceptibility to perioperative infections in clinical fracture management? A systematic review. Infection 2021, 49, 813-821. [CrossRef]

8. Costerton, J.W.; Lewandowski, Z.; Caldwell, D.E.; Korber, D.R.; Lappin-Scott, H.M. Microbial biofilms. Annu Rev. Microbiol. 1995, 49, 711-745. [CrossRef]

9. Andersson, D.I.; Hughes, D. Evolution of antibiotic resistance at non-lethal drug concentrations. Drug Resist. Updat. 2012, 15, 162-172. [CrossRef] [PubMed]

10. Andersson, D.I.; Hughes, D. Microbiological effects of sublethal levels of antibiotics. Nat. Rev. Microbiol. 2014, 12, 465-478. [CrossRef] [PubMed]

11. Chouirfa, H.; Bouloussa, H.; Migonney, V.; Falentin-Daudré, C. Review of titanium surface modification techniques and coatings for antibacterial applications. Acta Biomater. 2019, 83, 37-54. [CrossRef]

12. Shen, X.T.; Zhang, Y.Z.; Xiao, F.; Zhu, J.; Zheng, X.D. Effects on cytotoxicity and antibacterial properties of the incorporations of silver nanoparticles into the surface coating of dental alloys. J. Zhejiang. Univ. Sci. B 2017, 18, 615-625. [CrossRef]

13. Shivaram, A.; Bose, S.; Bandyopadhyay, A. Understanding long-term silver release from surface modified porous titanium implants. Acta Biomater. 2017, 58, 550-560. [CrossRef]

14. Campoccia, D.; Montanaro, L.; Arciola, C.R. A review of the biomaterials technologies for infection-resistant surfaces. Biomaterials 2013, 34, 8533-8554. [CrossRef] [PubMed]

15. Hasan, J.; Crawford, R.J.; Ivanova, E.P. Antibacterial surfaces: The quest for a new generation of biomaterials. Trends Biotechnol. 2013, 31, 295-304. [CrossRef]

16. Modaresifar, K.; Azizian, S.; Ganjian, M.; Fratila-Apachitei, L.E.; Zadpoor, A.A. Bactericidal effects of nanopatterns: A systematic review. Acta Biomater. 2019, 83, 29-36. [CrossRef]

17. Ivanova, E.P.; Hasan, J.; Webb, H.K.; Truong, V.K.; Watson, G.S.; Watson, J.A.; Baulin, V.A.; Pogodin, S.; Wang, J.Y.; Tobin, M.J.; et al. Natural bactericidal surfaces: Mechanical rupture of Pseudomonas aeruginosa cells by cicada wings. Small 2012, 8 , 2489-2494. [CrossRef] [PubMed]

18. Bandara, C.D.; Singh, S.; Afara, I.O.; Wolff, A.; Tesfamichael, T.; Ostrikov, K.; Oloyede, A. Bactericidal Effects of Natural Nanotopography of Dragonfly Wing on Escherichia coli. ACS Appl. Mater. Interfaces 2017, 9, 6746-6760. [CrossRef]

19. Linklater, D.P.; Juodkazis, S.; Rubanov, S.; Ivanova, E.P. Comment on “Bactericidal Effects of Natural Nanotopography of Dragonfly Wing on Escherichia coli". ACS Appl. Mater. Interfaces 2017, 9, 29387-29393. [CrossRef]

20. Zhou, J.; Li, B.; Zhao, L.; Zhang, L.; Han, Y. F-doped micropore/nanorod hierarchically patterned coatings for improving antibacterial and osteogenic activities of bone implants in bacteria-infected cases. ACS Biomater. Sci. Eng. 2017, 3, 1437-1450. [CrossRef] [PubMed]

21. Zhang, H.Z.; Sun, Y.; Tian, A.; Xue, X.X.; Wang, L.; Alquhali, A.; Bai, X.Z. Improved antibacterial activity and biocompatibility on vancomycin-loaded $\mathrm{TiO}_{2}$ nanotubes: In vivo and in vitro studies. Int. J. Nanomed. 2013, 8, 4379-4389. [CrossRef]

22. Guan, M.; Chen, Y.; Wei, Y.; Song, H.; Gao, C.; Cheng, H.; Li, Y.; Huo, K.; Fu, J.; Xiong, W. Long-lasting bactericidal activity through selective physical puncture and controlled ions release of polydopamine and silver nanoparticles-loaded $\mathrm{TiO}_{2}$ nanorods in vitro and in vivo. Int. J. Nanomed. 2019, 14, 2903-2914. [CrossRef] [PubMed]

23. Yang, Y.; Liu, L.; Luo, H.; Zhang, D.; Lei, S.; Zhou, K. Dual-purpose magnesium-incorporated titanium nanotubes for combating bacterial infection and ameliorating osteolysis to realize better osseointegration. ACS Biomater. Sci. Eng. 2019, 5, 5368-5383. [CrossRef]

24. Zhang, X.; Zhang, G.; Chai, M.; Yao, X.; Chen, W.; Chu, P.K. Synergistic antibacterial activity of physical-chemical multimechanism by $\mathrm{TiO}_{2}$ nanorod arrays for safe biofilm eradication on implant. Bioactive Mater. 2021, 6, 12-25. [CrossRef] 
25. Hooijmans, C.R.; Rovers, M.M.; de Vries, R.B.M.; Leenaars, M.; Ritskes-Hoitinga, M.; Langendam, M.W. SYRCLE's risk of bias tool for animal studies. BMC Med. Res. Methodol. 2014, 14, 43. [CrossRef] [PubMed]

26. Percie du Sert, N.; Hurst, V.; Ahluwalia, A.; Alam, S.; Avey, M.T.; Baker, M.; Browne, W.J.; Clark, A.; Cuthill, I.C.; Dirnagl, U.; et al. The ARRIVE guidelines 2.0: Updated guidelines for reporting animal research. Br. J. Pharmacol. 2020, 177, 3617-3624. [CrossRef] [PubMed]

27. López-Valverde, N.; Macedo-de-Sousa, B.; López-Valverde, A.; Ramírez, J.M. Effectiveness of Antibacterial Surfaces in Osseointegration of Titanium Dental Implants: A Systematic Review. Antibiotics 2021, 10, 360. [CrossRef] [PubMed]

28. Diu, T.; Faruqui, N.; Sjöström, T.; Lamarre, B.; Jenkinson, H.F.; Su, B.; Ryadnov, M.G. Cicada-inspired cell-instructive nanopatterned arrays. Sci. Rep. 2014, 4, 7122. [CrossRef]

29. Kelleher, S.M.; Habimana, O.; Lawler, J.; O'reilly, B.; Daniels, S.; Casey, E.; Cowley, A. Cicada wing surface topography: An investigation into the bactericidal properties of nanostructural features. ACS Appl. Mater. Interfaces 2016, 8, 14966-14974. [CrossRef] [PubMed]

30. Bürgers, R.; Gerlach, T.; Hahnel, S.; Schwarz, F.; Handel, G.; Gosau, M. In vivo and in vitro biofilm formation on two different titanium implant surfaces. Clin. Oral. Implants Res. 2010, 21, 156-164. [CrossRef]

31. Crawford, R.J.; Webb, H.K.; Truong, V.K.; Hasan, J.; Ivanova, E.P. Surface topographical factors influencing bacterial attachment. Adv. Colloid Interface Sci. 2012, 179-182, 142-149. [CrossRef] [PubMed]

32. Zhang, B.; Luo, Y.; Pearlstein, A.J.; Aplin, J.; Liu, Y.; Bauchan, G.R.; Payne, G.F.; Wang, Q.; Nou, X.; Millner, P.D. Fabrication of biomimetically patterned surfaces and their application to probing plant-bacteria interactions. ACS Appl. Mater. Interfaces 2014, 6, 12467-12478. [CrossRef] [PubMed]

33. Vasudevan, R.; Kennedy, A.J.; Merritt, M.; Crocker, F.H.; Baney, R.H. Microscale patterned surfaces reduce bacterial foulingmicroscopic and theoretical analysis. Coll. Surf. B Biointerfaces 2014, 117, 225-232. [CrossRef]

34. Ge, X.; Leng, Y.; Lu, X.; Ren, F.; Wang, K.; Ding, Y.; Yang, M. Bacterial responses to periodic micropillar array. J. Biomed. Mater. Res. A 2015, 103, 384-396. [CrossRef]

35. Valle, J.; Burgui, S.; Langheinrich, D.; Gil, C.; Solano, C.; Toledo-Arana, A.; Helbig, R.; Lasagni, A.; Lasa, I. Evaluation of surface microtopography engineered by direct laser interference for bacterial anti-biofouling. Macromol. Biosci. 2015, 15, 1060-1069. [CrossRef]

36. Liu, W.; Su, P.; Gonzales, A., 3rd; Chen, S.; Wang, N.; Wang, J.; Li, H.; Zhang, Z.; Webster, T.J. Optimizing stem cell functions and antibacterial properties of $\mathrm{TiO}_{2}$ nanotubes incorporated with $\mathrm{ZnO}$ nanoparticles: Experiments and modeling. Int. J. NanoMed. 2015, 10, 1997-2019. [CrossRef] [PubMed]

37. Gunputh, U.F.; Le, H.; Handy, R.D.; Tredwin, C. Anodised $\mathrm{TiO}_{2}$ nanotubes as a scaffold for antibacterial silver nanoparticles on titanium implants. Mater. Sci. Eng. C Mater. Biol. Appl. 2018, 91, 638-644. [CrossRef] [PubMed]

38. Cheng, Y.F.; Zhang, J.Y.; Wang, Y.B.; Li, C.M.; Lu, Z.S.; Hu, X.F.; Xu, L.Q. Deposition of catechol-functionalized chitosan and silver nanoparticles on biomedical titanium surfaces for antibacterial application. Mater. Sci. Eng. C Mater. Biol. Appl. 2019, 98, 649-656. [CrossRef]

39. Ahmed, K.B.A.; Raman, T.; Veerappan, A. Future prospects of antibacterial metal nanoparticles as enzyme inhibitor. Mater. Sci. Eng. C Mater. Biol. Appl. 2016, 68, 939-947. [CrossRef]

40. Kheiri, S.; Liu, X.; Thompson, M. Nanoparticles at biointerfaces: Antibacterial activity and nanotoxicology. Coll. Surf. B Biointerfaces 2019, 184, 110550. [CrossRef]

41. Park, H.J.; Kim, J.Y.; Kim, J.; Lee, J.H.; Hahn, J.S.; Gu, M.B.; Yoon, J. Silver-ion-mediated reactive oxygen species generation affecting bactericidal activity. Water Res. 2009, 43, 1027-1032. [CrossRef] [PubMed]

42. Vimbela, G.V.; Ngo, S.M.; Fraze, C.; Yang, L.; Stout, D.A. Antibacterial properties and toxicity from metallic nanomaterials. Int. J. Nanomed. 2017, 12, 3941-3965. [CrossRef]

43. Li, J.; Tan, L.; Liu, X.; Cui, Z.; Yang, X.; Yeung, K.W.K.; Chu, P.K.; Wu, S. Balancing bacteria-osteoblast competition through selective physical puncture and biofunctionalization of $\mathrm{ZnO} /$ polydopamine/arginine-glycine-aspartic acid-cysteine nanorods. ACS Nano 2017, 11, 11250-11263. [CrossRef] [PubMed]

44. Anitha, S.; Muthukumaran, S. Structural, optical and antibacterial investigation of La, Cu dual doped ZnO nanoparticles prepared by co-precipitation method. Mater. Sci. Eng. C Mater. Biol. Appl. 2020, 108, 110387. [CrossRef] [PubMed]

45. Zhang, L.; Zhang, L.; Yang, Y.; Zhang, W.; Lv, H.; Yang, F.; Lin, C.; Tang, P. Inhibitory effect of super-hydrophobicity on silver release and antibacterial properties of super-hydrophobic $\mathrm{Ag} / \mathrm{TiO}_{2}$ nanotubes. J. Biomed. Mater. Res. B Appl. Biomater. 2016, 104, 1004-1012. [CrossRef]

46. Yang, Z.; Gu, H.; Sha, G.; Lu, W.; Yu, W.; Zhang, W.; Fu, Y.; Wang, K.; Wang, L. TC4/Ag metal matrix nanocomposites modified by friction stir processing: Surface characterization, antibacterial property, and cytotoxicity in vitro. ACS Appl. Mater. Interfaces 2018, 10, 41155-41166. [CrossRef]

47. Gunputh, U.F.; Le, H.; Lawton, K.; Besinis, A.; Tredwin, C.; Handy, R.D. Antibacterial properties of silver nanoparticles grown in situ and anchored to titanium dioxide nanotubes on titanium implant against Staphylococcus aureus. Nanotoxicology 2020, 14, 97-110. [CrossRef]

48. Deshmukh, S.P.; Mullani, S.B.; Koli, V.B.; Patil, S.M.; Kasabe, P.J.; Dandge, P.B.; Pawar, S.A.; Delekar, S.D. Ag nanoparticles connected to the surface of $\mathrm{TiO}_{2}$ electrostatically for antibacterial photoinactivation studies. Photochem. Photobiol. 2018, 94, 1249-1262. [CrossRef] 
49. Bala Subramaniyan, S.; Megarajan, S.; Vijayakumar, S.; Mariappan, M.; Anbazhagan, V. Evaluation of the toxicities of silver and silver sulfide nanoparticles against Gram-positive and Gram-negative bacteria. IET Nanobiotechnol. 2019, 13, 326-331. [CrossRef]

50. Mohamed, D.S.; Abd El-Baky, R.M.; Sandle, T.; Mandour, S.A.; Ahmed, E.F. Antimicrobial activity of silver-treated bacteria against other multi-drug resistant pathogens in their environment. Antibiotics 2020, 9, 181. [CrossRef]

51. Yang, Z.; Ma, C.; Wang, W.; Zhang, M.; Hao, X.; Chen, S. Fabrication of $\mathrm{Cu}_{2} \mathrm{O}-\mathrm{Ag}$ nanocomposites with enhanced durability and bactericidal activity. J. Colloid. Interface Sci. 2019, 557, 156-167. [CrossRef]

52. Lai, Y.; Dong, L.; Zhou, H.; Yan, B.; Chen, Y.; Cai, Y.; Liu, J. Coexposed nanoparticulate Ag alleviates the acute toxicity induced by ionic $\mathrm{Ag}^{+}$in vivo. Sci. Total Environ. 2020, 723, 138050. [CrossRef]

53. AshaRani, P.V.; Low Kah Mun, G.; Hande, M.P.; Valiyaveettil, S. Cytotoxicity and genotoxicity of silver nanoparticles in human cells. ACS Nano 2009, 3, 279-290. [CrossRef] [PubMed]

54. Gao, C.; Cheng, H.; Xu, N.; Li, Y.; Chen, Y.; Wei, Y.; Gao, B.; Fu, J.; Huo, K.; Xiong, W. Poly(dopamine) and Ag nanoparticle-loaded $\mathrm{TiO}_{2}$ nanotubes with optimized antibacterial and ROS-scavenging bioactivities. Nanomedicine 2019, 14, 803-818. [CrossRef] [PubMed]

55. Zhou, J.; Li, B.; Han, Y. F-doped $\mathrm{TiO}_{2}$ microporous coating on titanium with enhanced antibacterial and osteogenic activities. Sci. Rep. 2018, 8, 17858. [CrossRef] [PubMed]

56. Tran, P.A.; O’Brien-Simpson, N.; Palmer, J.A.; Bock, N.; Reynolds, E.C.; Webster, T.J.; Deva, A.; Morrison, W.A.; O'Connor, A.J. Selenium nanoparticles as anti-infective implant coatings for trauma orthopedics against methicillin-resistant Staphylococcus aureus and epidermidis: In vitro and in vivo assessment. Int. J. Nanomed. 2019, 14, 4613-4624. [CrossRef]

57. Yonezawa, K.; Kawaguchi, M.; Kaneuji, A.; Ichiseki, T.; Iinuma, Y.; Kawamura, K.; Shintani, K.; Oda, S.; Taki, M.; Kawahara, N. Evaluation of antibacterial and cytotoxic properties of a fluorinated diamond-like carbon coating for the development of antibacterial medical implants. Antibiotics 2020, 9, 495. [CrossRef]

58. Wang, Y.; Zhang, S.; Zeng, X.; Ma, L.L.; Weng, W.; Yan, W.; Qian, M. Osteoblastic cell response on fluoridated hydroxyapatite coatings. Acta Biomater. 2007, 3, 191-197. [CrossRef]

59. Zhou, J.; Zhao, L. Multifunction Sr, Co and F co-doped microporous coating on titanium of antibacterial, angiogenic and osteogenic activities. Sci. Rep. 2016, 6, 29069. [CrossRef]

60. Li, D.; Lv, P.; Fan, L.; Huang, Y.; Yang, F.; Mei, X.; Wu, D. The immobilization of antibiotic-loaded polymeric coatings on osteoarticular Ti implants for the prevention of bone infections. Biomater. Sci. 2017, 5, 2337-2346. [CrossRef] [PubMed]

61. Mohan Raj, R.; Priya, P.; Raj, V. Gentamicin-loaded ceramic-biopolymer dual layer coatings on the Ti with improved bioactive and corrosion resistance properties for orthopedic applications. J. Mech. Behav. Biomed. Mater. 2018, 82, 299-309. [CrossRef] [PubMed]

62. Baghdan, E.; Raschpichler, M.; Lutfi, W.; Pinnapireddy, S.R.; Pourasghar, M.; Schäfer, J.; Schneider, M.; Bakowsky, U. Nano spray dried antibacterial coatings for dental implants. Eur. J. Pharm. Biopharm. 2019, 139, 59-67. [CrossRef]

63. Esteban, J.; Vallet-Regí, M.; Aguilera-Correa, J.J. Antibiotics-and heavy metals-based titanium alloy surface modifications for local prosthetic joint infections. Antibiotics 2021, 10, 1270. [CrossRef] [PubMed]

64. Salwiczek, M.; Qu, Y.; Gardiner, J.; Strugnell, R.A.; Lithgow, T.; McLean, K.M.; Thissen, H. Emerging rules for effective antimicrobial coatings. Trends Biotechnol. 2014, 32, 82-90. [CrossRef]

65. Acosta, S.; Ibañez-Fonseca, A.; Aparicio, C.; Rodríguez-Cabello, J.C. Antibiofilm coatings based on protein-engineered polymers and antimicrobial peptides for preventing implant-associated infections. Biomater. Sci. 2020, 8, 2866-2877. [CrossRef] [PubMed]

66. Wang, S.H.; Tang, T.W.; Wu, E.; Wang, D.W.; Liao, Y.D. Anionic surfactant-facilitated coating of antimicrobial peptide and antibiotic reduces biomaterial-associated infection. ACS Biomater. Sci. Eng. 2020, 6, 4561-4572. [CrossRef]

67. Lipsky, B.A.; Berendt, A.R.; Cornia, P.B.; Pile, J.C.; Peters, E.J.; Armstrong, D.G.; Deery, H.G.; Embil, J.M.; Joseph, W.S.; Karchmer, A.W.; et al. Infectious Diseases Society of America clinical practice guideline for the diagnosis and treatment of diabetic foot infections. Clin. Infect. Dis. 2012, 54, e132-e173. [CrossRef]

68. Tan, T.L.; Kheir, M.M.; Tan, D.D.; Parvizi, J. Polymicrobial periprosthetic joint infections: Outcome of treatment and identification of risk factors. J. Bone Joint Surg. Am. 2016, 98, 2082-2088. [CrossRef]

69. Puca, V.; Marulli, R.Z.; Grande, R.; Vitale, I.; Niro, A.; Molinaro, G.; Prezioso, S.; Muraro, R.; Di Giovanni, P. Microbial species isolated from infected wounds and antimicrobial resistance analysis: Data emerging from a three-years retrospective study. Antibiotics 2021, 10, 1162. [CrossRef]

70. Simchi, A.; Tamjid, E.; Pishbin, F.; Boccaccini, A.R. Recent progress in inorganic and composite coatings with bactericidal capability for orthopaedic applications. Nanomedicine 2011, 7, 22-39. [CrossRef]

71. Hickok, N.J.; Shapiro, I.M. Immobilized antibiotics to prevent orthopaedic implant infections. Adv. Drug. Deliv. Rev. 2012, 64, 1165-1176. [CrossRef] [PubMed]

72. Nguyen-Tri, P.; Tran, H.N.; Plamondon, C.O.; Tuduri, L.; Vo, D.-V.N.; Nanda, S.; Mishra, A.; Chao, H.-P.; Bajpai, A.K. Recent progress in the preparation, properties and applications of superhydrophobic nano-based coatings and surfaces: A review. Prog. Org. Coat. 2019, 132, 235-256. [CrossRef]

73. Muthukrishnan, G.; Masters, E.A.; Daiss, J.L.; Schwarz, E.M. Mechanisms of immune evasion and bone tissue colonization that make Staphylococcus aureus the primary pathogen in Osteomyelitis. Curr. Osteoporos Rep. 2019, 17, 395-404. [CrossRef]

74. Kavanagh, N.; Ryan, E.J.; Widaa, A.; Sexton, G.; Fennell, J.; O’Rourke, S.; Cahill, K.C.; Kearney, C.J.; O’Brien, F.J.; Kerrigan, S.W. Staphylococcal Osteomyelitis: Disease progression, treatment challenges, and future directions. Clin. Microbiol. Rev. 2018, 31, e00084-17. [CrossRef] [PubMed] 
75. Anagnostakos, K.; Sahan, I. Are cement spacers and beads loaded with the correct antibiotic(s) at the site of periprosthetic hip and knee joint infections? Antibiotics 2021, 10, 143. [CrossRef]

76. Moher, D.; Liberati, A.; Tetzlaff, J.; Altman, D.G. Preferred reporting items for systematic reviews and meta-analyses: The PRISMA statement. PLoS Med. 2009, 6, e1000097. [CrossRef] [PubMed] 